\title{
Urgences
}

\section{Conte oriental du travesti mort en chantant}

\section{Hugues Corriveau}

Numéro 15, octobre 1986

Épigraphiques

URI : https://id.erudit.org/iderudit/025337ar

DOI : https://doi.org/10.7202/025337ar

Aller au sommaire du numéro

Éditeur(s)

Urgences

ISSN

0226-9554 (imprimé)

1927-3924 (numérique)

Découvrir la revue

Citer ce document

Corriveau, H. (1986). Conte oriental du travesti mort en chantant. Urgences, (15), 76-76. https://doi.org/10.7202/025337ar d'utilisation que vous pouvez consulter en ligne.

https://apropos.erudit.org/fr/usagers/politique-dutilisation/ 


\section{Hugues Corriveau \\ CONTE ORIENTAL DU TRAVESTI MORT EN CHANTANT}

[...] sorte de poussah à la figure et à la voix pleines de cicatrices [...]

Marcel Proust: À l'ombre des jeunes filles en fleurs

Étouffé dans son obésité, plein, à cause d'une sorte particulière de gras, il chante tout de même. Le visqueux des pores l'empêche de pousser sa voix jusque-là, jusqu'au si, tant à la joue l'air gonfle, succédané oléagineux, l'épaisseur épidermique et l'huile capillaire. La diva figure ici l'opale splendeur d'un couac où, pleine d'air et actrice, elle pousserait aux cordes l'extrême tension triste de sa fin, travestie. "Sancte Iohannes", la note près du délire, le chanteur est poussé à se prendre pour une cantatrice, dénote, dans la figure de sa voix pleine, la vieillesse sonore de ses cordes. Il y voit si bien, que sortent de l'aine les sueurs morbides où sa figure craquelle et desquame. Il balance, il roule sur lui-même jusqu'à l'infinie tristesse où il se fige enfin. Mouvements arrêtés, voix ouverte sur la brisure sonore, morte en plein songe de ce qu'il n'était pas, il s'avérait tout juste une sorte de poussah, trompé en plein chant par la fissure rouge de ses lèvres, suture de la bouche, enfin silencieux, extatique et mort. 